\title{
aniki
}

Revista Portuguesa da Imagem em Movimento

Portuguese Journal of the Moving Image

\section{Corpo e política:}

Gênero, sexualidade e intimidade em Boi Neon Fabio Zoboli ${ }^{1}$, Renato Izidoro da Silva ${ }^{2}$, Eduardo Galak ${ }^{3}$

\section{Introdução}

[...] la política es asunto de seres hablantes. Es lo mismo que decir que es asunto de cuerpos hablantes, porque no hablarían si no tuvieran cuerpo. Pero, a su vez, si tuvieran solo cuerpos y no hablasen, no tendrían necesidad de política [...]. Mientras habla, concluye que no encontrará sino semejantes, es decir, cuerpos de los que hará semblante de admitir, por civismo, que hablan como él, aunque con la reserva de que lo hacen porque son su eco. Ser el único en hablar no significa el silencio generalizado, sino un entrecruzamiento de resonancias (Milner 2013, 12).

Este escrito tem como objetivo compreender os usos políticos do corpo no texto fílmico de Boi Neon. Parte-se do entendimento de Jean-Claude Milner $(2013,18)$ de que a política se reduz a técnicas do corpo e que, segundo Marcel Mauss (1974, 385), as técnicas corporais são "as maneiras como os homens, sociedade por sociedade e de maneira tradicional, sabem servir-se de seus corpos". Assim, é possível identificar discursos políticos e sentidos estéticos inscritos nos corpos dos personagens nordestinos do filme. As inscrições são políticas porque as relações corporais são historicamente constituídas (registradas, memorizadas, documentadas, arquivadas) por mediações (regras e leis) subjetivas e objetivas, responsáveis por estabelecer comportamentos coordenados no interior de um campo ou sistema social, cujas formas se expressam e se condicionam nas dimensões das práticas culturais. Isto é, as condições de um agrupamento social se reproduzem na dinâmica das permanências e das mudanças provocadas no desenvolvimento das práticas culturais e nas subjetividades.

Na modernidade, o corpo anátomo-biológico da ciência foi se transformando, articulado com a técnica, num objeto da política, na medida em que a racionalidade científica começou a ser pensada

\footnotetext{
${ }^{1}$ Universidade Federal de Sergipe, Departamento de Educação Física, 49100-000, São Cristóvão - SE, Brasil.

${ }^{2}$ Universidade Federal de Sergipe, Departamento de Educação Física, 49100-000, São Cristóvão - SE, Brasil.

${ }^{3}$ Universidade Nacional de La Plata, Faculdade de Humanidades e Ciências da Educação, calle 51 entre 124-125, Ensenada (1925), Buenos Aires, Argentina.
} 
para promover o desenvolvimento das forças produtivas da sociedade. Sob o viés foucaultiano, o governo da população foi possível por uma política estatal de regulação das práticas, cujos corpos passaram a ser vistos sob o viés da anatomia política. Para Foucault (2001), a "anatomia política" é uma "mecânica de poder" que define como se pode ter domínio sobre o corpo dos outros, não simplesmente para que façam o que se quer, mas para que operem como se quer, com técnicas, segundo rapidez e eficácia que se determina. Como afirma Milner, "las libertades políticas empiezan y terminan por los cuerpos. Las dictaduras siempre la toman con los cuerpos. Aclaremos: con su anatomía y con su fisiología" $(2013,18)$.

A política pode ser pensada de forma ampla como gestão e regulação dos comportamentos responsáveis por produzirem mediadores que condicionam conteúdos e formas para as relações humanas. Isso significa que a política se realiza, entre outros, por meios e fins jurídicos e morais, sobre os quais o Estado e o direito se ocupam em termos antropológicos. A gestão das subjetividades está materialmente inscrita e suportada pelos corpos regulados por regras e valores culturalmente relativos que, em última instância, implicam técnicas corporais que, em meio à pluralidade dos seres falantes ${ }^{4}$ (massa/população), tentam impor algum tipo de limite para condicionar comportamentos adequados dentro de uma sociedade organizada para além das vontades individuais (Milner, 2013).

O filme Boi Neon (2015), dirigido pelo cineasta brasileiro Gabriel Mascaro, é uma obra nascida do ventre do "cinema pernambucano", que tem como característica uma certa auto-referencialidade: as relações políticas características da história cultural e econômica do Nordeste brasileiro são refletidas nas hexis corporais dos protagonistas. ${ }^{7}$

\footnotetext{
${ }^{4}$ A expressão "seres falantes" tem nesse texto uma referência direta a Aristóteles, que pensa os homens enquanto seres políticos por serem animais que falam.

${ }^{5}$ Gabriel Mascaro, nascido em Recife-PE (Brasil) em 1983. É um cineasta que iniciou fazendo documentários no ano de 2008. Em 2014 lançou seu primeiro filme, Ventos de Agosto, porém seu nome se evidencia no âmbito do cinema nacional brasileiro após lançar em 2015 o filme Boi Neon. Além dessas duas obras, sua filmografia é composta por: KFZ-1948 (documentário, 2008), Um Lugar ao Sol (documentário, 2009), As Aventuras de Paulo Bruscky (curta-metragem, 2010), A Onda traz, o Vento leva (curta-metragem, 2012), e Doméstica (documentário, 2012).

${ }^{6}$ Tornou-se comum historicamente localizar o "cinema pernambucano" a partir da retomada do cinema brasileiro após os atos do governo Fernando Collor de Mello, que extinguiu as instituições federais no fomento as artes brasileiras, em especial a Empresa Brasileira de Filmes - EMBRAFILME, em 16/03/1990, através do Programa Nacional de Desestatização (PND). Doravante, os cineastas pernabucanos configuraram um polo cinematográfico importante no país. Contudo, é importante frisar que Recife tem uma importância na historiografia cinematográfica do Brasil; quando de dois momentos do século passado: o "Ciclo do Recife" (no início dos anos de 1920) (FIGUEIRÔA, 2010) e o "Movimento Super-8" (na década de 1970) (FIGUEIRÔA, 2000).

${ }^{7}$ O Nordeste é uma das cinco regiões do Brasil, e é composto por nove estados: Bahia, Sergipe, Alagoas, Pernambuco, Rio Grande do Norte, Ceará, Paraíba, Piauí e
} 
Boi Neon narra o dia-a-dia de uma equipe de trabalhadores da vaquejada, ${ }^{8}$ evento itinerante que percorre as cidades do interior da região, aos modos dos antigos circos. Apoiados em nosso pressuposto acerca das práticas políticas ensejadas pela dimensão corpórea da contemporânea vida cultural econômica neoliberal, observamos a película tecida pela exposição invertida dos mediadores tradicionais das dicotômicas relações sociais entre seus personagens, na construção da narrativa em sua estética moderna: masculino/feminino; homem/animal; público/privado. A sinopse do filme o apresenta da seguinte maneira:

Nos bastidores das Vaquejadas, Iremar e um grupo de vaqueiros preparam os bois antes de soltá-los na arena. Levando a vida na estrada, o caminhão que transporta os bois para o evento é também a casa improvisada de Iremar e seus colegas de trabalho: Zé, Negão, Galega e sua filha Cacá. O cotidiano é intenso e visceral, mas algo inspira novas ambições em Iremar: a recente industrialização e o polo de confecção de roupas na região do semiárido nordestino. Deitado em sua rede na traseira do caminhão, sua cabeça divaga em sonhos de lantejoulas, tecidos requintados e croquis. O vaqueiro esboça novos desejos (Boi Neon, 2015).

A narrativa fílmica de Mascaro nos apresenta questões políticas no que tange aos usos do corpo, ao narrar em sua diegese fílmica as técnicas corporais tradicionalmente adquiridas e eficazmente incorporadas no contexto das relações de poder reconhecidas no Nordeste rural. Assim, o objetivo deste texto é interpelar questões políticas que giram em torno do corpo a partir da mirada do gênero, da sexualidade e da intimidade em Boi Neon.

Este texto parte do pressuposto de que o cinema funciona como dispositivo de difusão de discursos políticos e estéticos, que tensionam técnicas do corpo e que mediatizam as relações humanas no campo da economia e da cultura. A ideia de pensar corpo e política em Boi Neon está intrínseca ao que caracteriza o cinema como uma representação visual e sonora criada a partir da montagem articulada entre signos. Para Deleuze (2009), o nascimento do cinema possibilita pensar novas dimensões estéticas e políticas, pois o cinema reflete toda uma racionalidade científica, ordenada e metódica. O cinema é, assim, o resultado da

Maranhão. Em meio às inúmeras problemáticas sócio-econômicas herdadas do colonialismo e perpetuadas pelo imperialismo capitalista, a região é um berço de cultura diversa, com riqueza e economia amplamente plurais, como muito bem aponta - nas linhas e entrelinhas - o filme de Gabriel Mascaro.

${ }^{8}$ Vaquejada é uma prática cultural nordestina em que dois vaqueiros entram numa arena, cada qual montado em um cavalo. Um boi é solto e ele é encurralado pelos vaqueiros que o derrubam, puxando-o pelo rabo, enquanto corre num espaço delimitado por duas faixas de cal feitas no chão. Esta atividade vem sendo questionada constantemente por ativistas que lutam pelos direitos dos animais, que vinculam a vaquejada a maus tratos, ao mesmo tempo que é mantida como prática cultural argumentada pelos seus defensores por sentidos tradicionalistas e conservadores. 
racionalidade técnica entre câmera e montagem. A racionalidade do cinema é um equilíbrio entre o dinâmico e o uniforme, um equilíbrio dinâmico de luzes e sombras que produz o efeito de movimento cine movimento. De igual forma, o cinema é o resultado de uma uniformidade onde técnicas de captura e montagem são a consequência de uma sucessão equidistante das imagens - cine tempo (Galak 2017).

A estruturação técnica de "montar" um filme já traz em si uma conotação política na medida em que no momento da sua construção o diretor gerencia os fundamentos estratégicos das relações que irão compor a sua obra a fim de gerar uma estética no espectador. Estas dimensões são definidas pelo diretor quando seleciona quadros e planos; determina um ritmo de imagem e movimento para cada uma das cenas; elege elementos gráficos e sonoros para construir suas narrativas; situa silêncio nas palavras; joga com o que mostrar e o que não mostrar. Do mesmo modo, "montar" um cavalo para derrubar um boi na vaquejada traz intrínsecas as dimensões da técnica e da política. Para sua prática, a vaquejada exige toda uma técnica corporal, pela qual o peão precisa articular o domínio da natureza através da realização de movimentos corporais consonantes com o cavalo, o boi e o espaço da arena, a fim de atingir um resultado/fim, respeitando as regras que impõem os limites para condicionar comportamentos adequados dentro da prática que é regida por regras.

Se pensarmos o cinema como um produto da cultura, que não apenas reflete uma realidade, mas também a sustenta - produz e reproduz -, podemos mencionar que o corpo, no âmbito das narrativas fílmicas, aparece coerente a um contexto de verdades, na medida em que não causa estranhamento nos seus modos de figurar. Se mudarmos a mirada e pensarmos o cinema enquanto arte, veremos nele a tentativa de desarticular os modos estéticos e políticos produzidos pela sociedade para educar os corpos. "Las imágenes del arte son operaciones que producen un distanciamiento, una desemejanza" (Rancière 2011b, 28). ${ }^{9} \mathrm{O}$ cinema enquanto arte é um dispositivo que propõe uma determinada resistência às normas $\mathrm{e}$ aos valores estabelecidos, no que tange às técnicas do corpo convencionais. "Pero ambas maneras de poner en relación la constitución de una forma material y la de un espacio simbólico son tal vez los dos fragmentos de una misma configuración originaria, ligando lo propio del arte a una cierta forma de ser de la comunidad" (Rancière 2011a, 35).

\footnotetext{
${ }^{9}$ É importante assinalar aqui a relevância da distância na teoria de Rancière, chave para nossa análise, porque mostra as múltiplas distinções que envolvem o cinema: a distância entre o espectador e a obra, entre uma imagem e a outra, entre um personagem e outro. Em parte, é possível rastrear este posicionamento teórico no debate que Rancière parece ter com a teoria dos intervalos do Dziga Vértov e com as distâncias que implicam a aura e as originalidades das obras em Walter Benjamin.
} 
Mesmo que a ficção - em maior ou menor grau - afete o corpo no contexto de uma narrativa fílmica, ele sempre estará preso a um território onde o espectador encontrará sentidos consonantes ao seu entorno social. Acreditamos que o fato de Boi Neon se enquadrar dentro do gênero cinematográfico ficcional não impede que o utilizemos como campo empírico-documental de nosso estudo. Como menciona Rancière, "o real precisa ser ficcionado para ser pensado" $(2009,59)$. "A política e a arte, tanto quanto os saberes, constroem ficções, isto é, rearranjos materiais dos signos e das imagens, das relações entre o que se vê e o que se diz, entre o que se faz e o que se pode fazer" (Rancière 2009, 59).

\section{Os usos políticos do corpo em Boi Neon}

No início de Boi Neon, uma cena traduz o corpo enquanto base do político: Iremar - um dos protagonistas do filme - caminha por um terreno baldio de solo úmido, oriundo de um tapume que seca num nordeste surrado pelo sol. Cinema de fluxo, a ação discorre por um plano sequência, em grande conjunto, de um minuto e meio, ao mesmo tempo em que a câmera está em travelling enquanto explora a profundidade de campo. Ao fundo se vê um caminhão com um homem despejando restos de tecido e pedaços quebrados de manequins (bonecos). Iremar recolhe pedaços rotos desses manequins, na tentativa de formar um corpo de boneco que usará posteriormente como modelo para vestir as roupas que fabrica durante as horas de folga do trabalho de vaquejada. A cena termina com Iremar retirando uma cabeça de manequim parcialmente enterrada ao lodacento solo.

O corpo do modelo de Iremar é montado a partir de "pedaços" de outros manequins. Ambas as cenas podem ser a metáfora de que os corpos trazem inscrições de um lugar/território; são metáforas de que o corpo, em meio a um contexto cultural, contracena interatuando com outros corpos produzidos por técnicas comuns. A política de certas relações entre diferentes corpos, assim como a significação (e ponderação) de certas partes do corpo, são todas operações básicas de fixação que naturalizam as técnicas corporais dentro de um contexto cultural.

\section{Gênero e poder do/nos corpos}

Uma questão política nos usos sociais do corpo exibida no filme é a temática do gênero. "A natureza humana é um efeito da tecnologia social que reproduz nos corpos, nos espaços e nos discursos a equação: natureza = heterossexualidade" (Preciado 2014, 25). Decorrente dessa estrutura, os genitais passam a demarcar a heteronormatividade a partir de categorias que gestam políticas mediadas por agenciamentos históricos de subjetivação na medida 
em que, além de ter um pênis ou uma vagina, o sujeito deve corresponder a comportamentos éticos, estéticos e culturais nas formas de relacionamentos existentes na sociedade conforme suas diferenças e semelhanças corporais.

A assimilação entre gênero e masculino/feminino, homem/mulher, macho/fêmea, atua assim para manter a naturalização que a noção de gênero pretende contestar. Assim, um discurso restritivo sobre gênero que insista no binarismo homem e mulher como a maneira exclusiva de entender o campo do gênero atua no sentido de efetuar uma operação reguladora de poder que naturaliza a instância hegemônica e exclui a possibilidade de pensar sua disrupção (Butler 2014, 254).

A trama fílmica cria rupturas nessa configuração histórica de gênero na divisão social do trabalho, principalmente com seus dois personagens centrais: Iremar (Juliano Cazarré) e Galega (Maeve Jinkings), que trabalham juntos no carregamento, transporte e preparação dos bovinos para serem utilizados no espetáculo da vaquejada. Iremar é um homem forte e valente que trabalha preparando (penteando) o rabo dos bois para serem puxados pelos vaqueiros no campo da vaquejada. Nas horas de folga, ele se ocupa desenhando e costurando roupas femininas e expressa um desejo de figurar no mundo da moda como estilista.

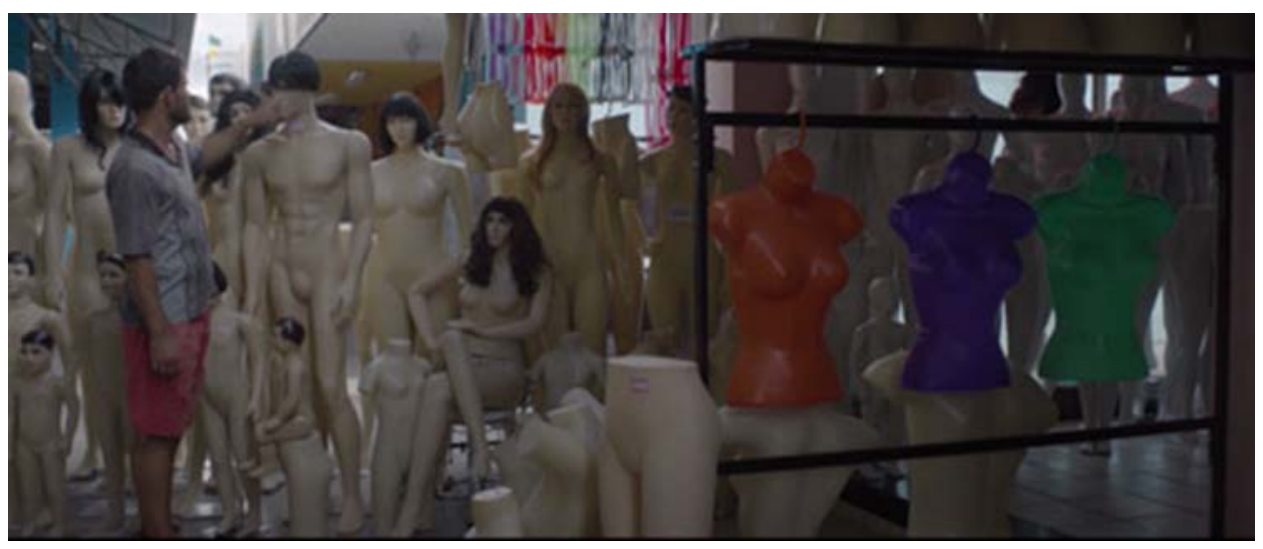

Imagem 1: Uma das cenas em que Iremar lida com seu interesse pela moda em Boi Neon (Gabriel Mascaro, 2015)| (c) Gabriel Mascaro

Galega trabalha como motorista do caminhão que transporta os bois de uma cidade a outra. A personagem apresenta conhecimentos e habilidades de mecânica de automóveis, ao encenar realizando reparos no caminhão. Sua filha Cacá (Aline Santana) acompanha Galega nas viagens de trabalho. Porém, essa insiste que a filha vá morar com o pai para poder estudar em uma escola.

Outros dois personagens que também tensionam a heteronormatividade de gênero são Geise (Samya De Lavor) e Júnior (Vinicius de Oliveira). Geise é uma mulher grávida que trabalha de guarda noturna numa indústria têxtil. Ela usa farda, calça 
coturno e em sua cintura carrega uma arma de fogo. Durante o dia vende produtos cosméticos via catálogode para um fabricante de produtos de beleza. Júnior tem cabelos compridos e em frente ao espelho aplica sobre eles uma máquina de alisamento e produtos cosméticos.

Podemos identificar que, no espaço fílmico de Boi Neon, o diretor Gabriel Mascaro joga com as questões de gênero, desconstruindo o contrato social heterocentrado, cujas performatividades normativas foram inscritas nos corpos como verdades históricas a partir de uma estrutura biológica de corpo. Deste modo, entendemos que Boi Neon está em consonância com as ideias de Beatriz Preciado, quando esta afirma que:

os corpos se reconhecem a si mesmos não como homens ou mulheres, e sim como corpos falantes, e reconhecem os outros corpos como falantes. Reconhecem em si mesmos a possibilidade de aceder a todas as práticas significantes, assim como a todas as posições de enunciação, enquanto sujeitos, que a história determinou como masculinas, femininas ou perversas. Por conseguinte, renunciam não só a uma identidade sexual fechada e determinada naturalmente, como também aos benefícios que poderiam obter de uma naturalização dos efeitos sociais, econômicos e jurídicos de suas práticas significantes. (Preciado 2014, 21)

\section{Sexualidade e tecnologia política}

As questões de gênero contracenam de modo próximo com as questões políticas da sexualidade na narrativa fílmica de Mascaro. Quando Butler afirma que "talvez o sexo sempre tenha sido o gênero, de tal forma que a distinção entre sexo e gênero revela-se absolutamente nenhuma" $(2014,25)$, ela está a indicar que o sexo não é natural, mas é também discursivo e cultural, como o gênero. Este entendimento de Butler tem relação com Foucault (2009), quando analisa a sexualidade como um dispositivo histórico de poder da modernidade, estabelecido por práticas discursivas e não discursivas que determinam uma concepção do indivíduo como sujeito de uma sexualidade dependente de saberes e poderes que buscam normatizar, controlar e constituir verdades acerca do sujeito na sua relação com o corpo sexuado e sensível aos prazeres da alteridade.

A sexualidade é uma invenção moderna: como afirma Anthony Giddens, "o prazer moderno se transforma em 'sexualidade' à medida que a sua investigação produz textos, manuais e estudos que distinguem a 'sexualidade normal' de seus domínios patológicos” (1993, 30). A partir da modernidade, a sexualidade passa a ser vista sob o viés da racionalidade e, por consequência, da correção terapêutica. "A preocupação com a sexualidade, incluindo a invenção da própria 'sexualidade', é o resultado do sucesso da 
vigilância como meio de gerar poder" (Giddens 1993, 188). A sexualidade passa a reger um emaranhado de técnicas de comportamento e percepções que são políticas porque estabelecem modos de relações culturais e econômicas entre os cidadãos, conforme as sociedades.

A natureza humana é um efeito da tecnologia social que reproduz nos corpos, nos espaços e nos discursos a equação: natureza = heterossexualidade. O sistema heterossexual é um dispositivo social de produção de feminilidade e masculinidade que opera por divisão e fragmentação do corpo: recorta órgãos e gera zonas de alta intensidade sensitiva e motriz (visual, tátil, olfativa...) que depois identifica como centros naturais e anatômicos da diferença sexual. (Preciado 2014, 25)

Neste sentido, a sexualidade como tecnologia pode intensificar ou amenizar a frequência e especificar os modos das relações humanas. Sobre isso o autor menciona que:

É hora de deixar de estudar e de descrever o sexo como parte da história natural das sociedades humanas. A 'história da humanidade' se beneficiaria se fosse rebatizada como 'história das tecnologias', sendo o sexo e o gênero dispositivos inscritos em um sistema tecnológico complexo. (Preciado 2014, 23)

A revista Playboy ${ }^{10}$, por exemplo, aparece no filme enquanto uma tecnologia política que através de sua enunciação discursiva faz figurar relações humanas, tendo como mote a sexualidade enquanto dispositivo de gênero. No longa metragem, um exemplar da revista passa pela mão de três personagens, mostrando os diferentes usos de um mesmo artefato cultural. Zé (Carlos Pessoa), um dos funcionários da equipe da vaquejada, parece ser o dono da revista, que possivelmente a utiliza para a prática da masturbação. Iremar aproveita o nu fotográfico das mulheres para desenhar e projetar (vestir ou encobrir com) os trajes que pretende costurar. Numa das cenas, Iremar manuseia a revista, cujas páginas estão coladas umas nas outras, supostamente por causa do esperma ejaculado por Zé durante a masturbação. Iremar expressa irritação, se dirigindo à Zé com tom de revolta. A irritação de Iremar também é com Cacá, que usou a revista para desenhar sua paixão pelos cavalos. Zé também reclama com Iremar por ele desenhar sobre a genitália das mulheres,

\footnotetext{
${ }^{10}$ A Playboy é uma revista de origem norte-americana fundada em 1953 por Hugh Hefner e teve como primeira celebridade estampada em sua capa a atriz Marilyn Monroe. Ao longo do tempo, a Playboy foi ganhando adeptos, leitores e interessados por todo o mundo e atualmente circula em 33 países. A revista chegou ao Brasil no ano de 1975, publicada pela Editora Abril, que mantém os direitos da mesma no território nacional até hoje (Costa e Zoboli 2014). A Playboy é uma referência frente aos inúmeros dispositivos de sexualidade no âmbito da cultura brasileira, no que tange à veiculação de imagens de mulheres nuas: a cada mês a Playboy apresenta alguma "celebridade feminina nacional" totalmente nua em suas páginas e gera expectativa no público masculino que as consome.
} 
retrucando com as seguintes frases: "Eu pago para ver a vagina das mulheres e tu fica riscando em cima delas. Eu quero outra!"

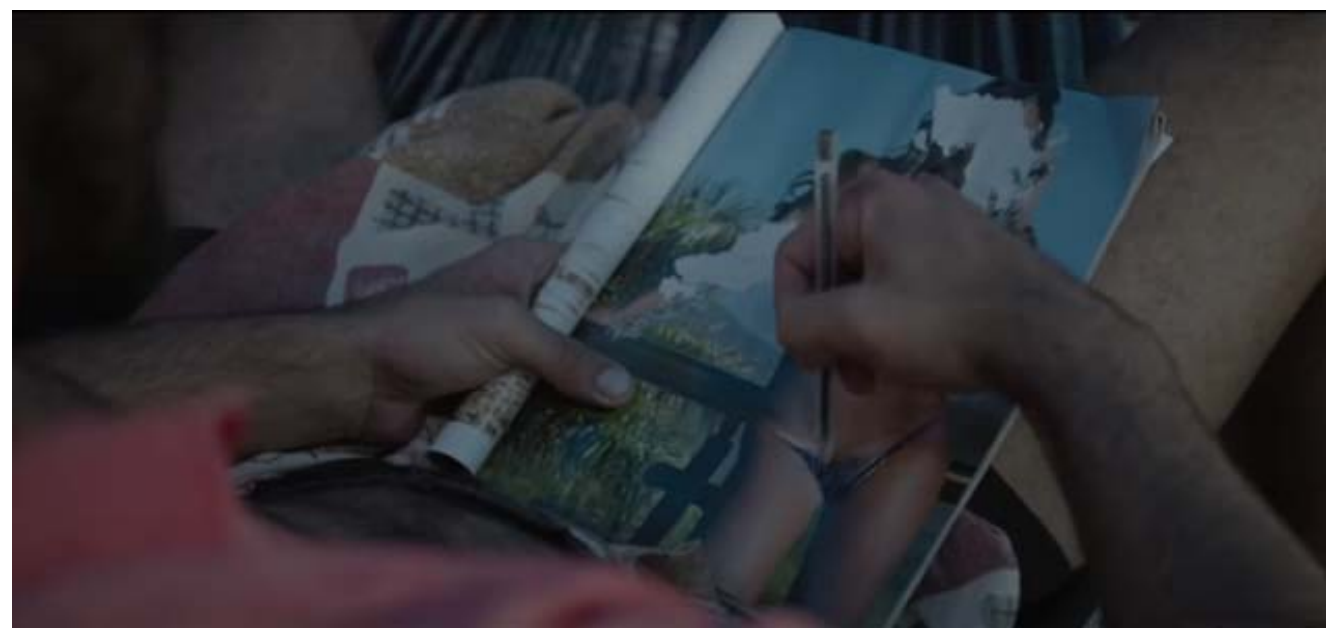

Imagem 2: Cena de Iremar desenhando um croqui de vestimenta sobre a fotografia de um nu de uma mulher na revista Playboy em Boi Neon (Gabriel Mascaro, 2015) | (c Gabriel Mascaro

A Playboy traz em suas páginas o desejo de três personagens: o de Cacá, que sonha em ter um cavalo; o de Iremar, de ser um estilista de moda; e o de Zé, que deseja o sexo da mulher nua estampada nas páginas da revista. Resulta importante refletir sobre os usos e os corpos que estas cenas exibem: a revista ao mesmo tempo destaca a comercialização de produtos e corpos eróticos e a masturbação, mostra corpos nus como manequins e expõe uma colagem organizada de fotografias. O efeito da contemporaneidade neoliberal constrói um artefato cultural para cada prática social, com a condição de ser efêmero, de poder tornar a ser comercializado, de ser sempre novidade. Como podemos afirmar com Giddens:

A sexualidade gera prazer; e o prazer, ou pelo menos a sua promessa, proporciona um incentivo para os produtos comercializados em uma sociedade capitalista. As imagens sexuais aparecem em quase toda parte no mercado como uma espécie de empreendimento comercial gigantesco; a transformação do sexo em mercadoria poderia então ser interpretada em termos de um movimento de ordem capitalista, dependente do trabalho, da disciplina e da autonegação, para uma ordem preocupada em incrementar o consumismo e, por isso, o hedonismo. (Giddens 1993, 194)

No imaginário popular, as revistas eróticas ou pornográficas possuem vínculos com a prática da masturbação, especialmente comum ao universo social da masculinidade. A prática do onanismo é historicamente marcada por um sem fim de tabus, inclusive alguns 
tratados médicos ${ }^{11}$ foram escritos com a intenção de regular os comportamentos ligados à contingência dessa prática sexual desviada de suas funções ligadas à constituição familiar por procriação. Ao lado das modalidades anal e oral, o sexo por masturbação não deixa de envolver um dado prazer contraceptivo, podendo ser realizado solitariamente ou com parceiros. Com algumas variações, o que esses tratados médicos tinham em comum era a descrição da prática masturbatória ligada a processos de degeneração moral e sua identificação patológica; a nosso ver, por conta de configurar modos substitutos das socializações normalizadas culturalmente.

$\mathrm{Na}$ transição do tato para a visão, que marcará a emergência da modernidade filosófica, o tato, enquanto sentido menos válido, será literalmente contido e efetivamente 'impedido' por meio de uma série de instrumentos técnicos que mediarão à relação entre a mão e os órgãos genitais, e que virão a regular as possibilidades inquietantes abertas pela mão que toca a si mesmo e que transforma o indivíduo em seu próprio objeto de conhecimento, de desejo e de prazer. (Preciado 2014, 100)

As relações entre sexualidade e artes visuais (cinema e fotografia) associadas à nudez estabelecem uma intimidade antes limitada aos poderes da imaginação e do sonho. A masturbação é uma prática visio-motora ou óculo-manual por excelência, fortemente mediada pelo universo das fantasias. Na masturbação, mas também no sexo compartilhado, o tato não é suficiente para gerar uma excitação representada pela ereção do pênis e do clitóris, bem como para elevar o corpo à experiência do gozo. A fantasia (mental, fotográfica, cinematográfica) sexual é elemento determinante para a ocorrência dos processos fisiológicos, às vezes independentes do tato.

Explorando essas vias, Boi Neon transita pelas fronteiras complexas, por vezes indistintas e confusas, da vida política da sexualidade socializada e mediada econômica e culturalmente, segundo as problemáticas entre o íntimo e o público. No caso da masturbação, embora não restrita à solidão, revela uma publicidade da sexualidade. Ao mesmo tempo que se trata de uma relação consigo, é também determinada e dependente da relação com a imagem do outro, então destituído de sua realidade privada e íntima; que, pela mediação das artes visuais, eróticas ou pornográficas, esse

\footnotetext{
${ }^{11}$ À guisa de exemplos, apresentamos: o tratado anônimo inglês publicado em 1716 na Holanda, denominado Onania, o hediondo pecado da autopolução; a obra $O$ onanismo: dissertação sobre as doenças produzidas pela masturbação, que em 1760 foi publicada pelo médico suíço Samuel Auguste Tissot; os estudos sobre a história das tecnologias sexuais de Vern Bullough (1928-2006), que apresenta uma enorme produção de aparelhos/instrumentos construídos entre os séculos XVIII e XIX dedicados à prevenção do que se passou a chamar de "doenças produzidas pela masturbação" - segundo Preciado (2014), somente no século XVIII a masturbação será construída médica e institucionalmente como uma "doença".
} 
outro visado está lançado no imaginário comum ou social a exemplo das revistas e dos filmes com conteúdos sexuais.

Essa questão se estende para além das artes visuais quando, em duas cenas do filme, uma mulher dança na noite em meio a luzes coloridas de um bordel para encantar os peões da vaquejada. Os espetáculos performáticos envolvendo a revelação da sexualidade íntima, ao modo do teatro, colocam o espectador em relação com uma imagem, embora o fenômeno dessa seja produzido pelo suporte corpo de "carne e osso". O palco estabelece o limite político da relação com o corpo/imagem sexualizado. Os espectadores não podem compartilhar, em princípio ou imediatamente, suas sexualidades com a pessoa do corpo especularmente capturado pelos olhos. A roupa da personagem deixa transparecer as bordas de sua nudez, mas o que impressiona na cena é que ela usa uma cabeça de égua. No corpo híbrido, mulher e animal se unem para fazer alusão ao sexo do animal, que é público, não é, para nós, íntimo ou vergonhoso.

Umberto Galimberti (2006) afirma que a grande diferença entre o animal e o homem é que o animal in-siste num mundo que para ele já está preordenado pelo seu corpo através dos aparatos instintivos, ao passo que o homem ex-siste, porque está fora de qualquer preordenação e, por efeito de sua ex-sistência, é obrigado a construir para si um mundo via uso da técnica. Nesse sentido, metaforizar sexo e mulher com a égua não significa reduzir a mulher à condição de animal, pois os animais também fazem sexo. No entanto, a metáfora reduz a mulher à condição de objeto ao reduzir seu corpo e seu sexo à imediatez dos sentidos do organismo, destituindo o sexo de sua dimensão política e cultural, bem como social e econômica. Metaforizar a mulher e o sexo com o animal significa não reconhecer o outro enquanto outro, e sim enquanto coisa que uso para satisfazer a "animalidade" sexual que carrego em meu organismo.

A mulher fantasiada de égua historicamente atualiza as tradicionais vaquejadas segundo a lógica neoliberal então capaz de submeter a natureza não apenas ao estatuto de propriedade, mas à condição de mercadoria sem rosto, anônima em sua sensibilidade historicamente associada ao feminino. O feminino da égua é um modo estético de sobrepor o selvagem da natureza à sua fragilidade a ser protegida. Enquanto selvagem, deve ser dominada e servir aos desígnios da fêmea sexuada no espetáculo. Contudo, inserida no contexto do bordel e da arena do rodeio, mulher e égua (ou vaca ou boi) são desviadas de seus fundamentos naturais: a beleza, o sexo, a procriação. Nesse desvio, a sexualidade se evidencia como mercadoria que funciona econômica e culturalmente em seus modos de relação então refletidas politicamente porque envolve posições, contratos, regras, leis, poderes. Os mesmos peões (homens) que montam e/ou laçam éguas, vacas e bois estão na posição de domínio 
da natureza em termos de desvio político de suas supostas finalidades naturais, para então inseri-los em teleologias culturais e econômicas. É se apresentando com tais elementos corporais do animal que a mulher propõe um modo de relação sexual mercadológica com o homem em detrimento de outros possíveis, especialmente aqueles que levariam à procriação.

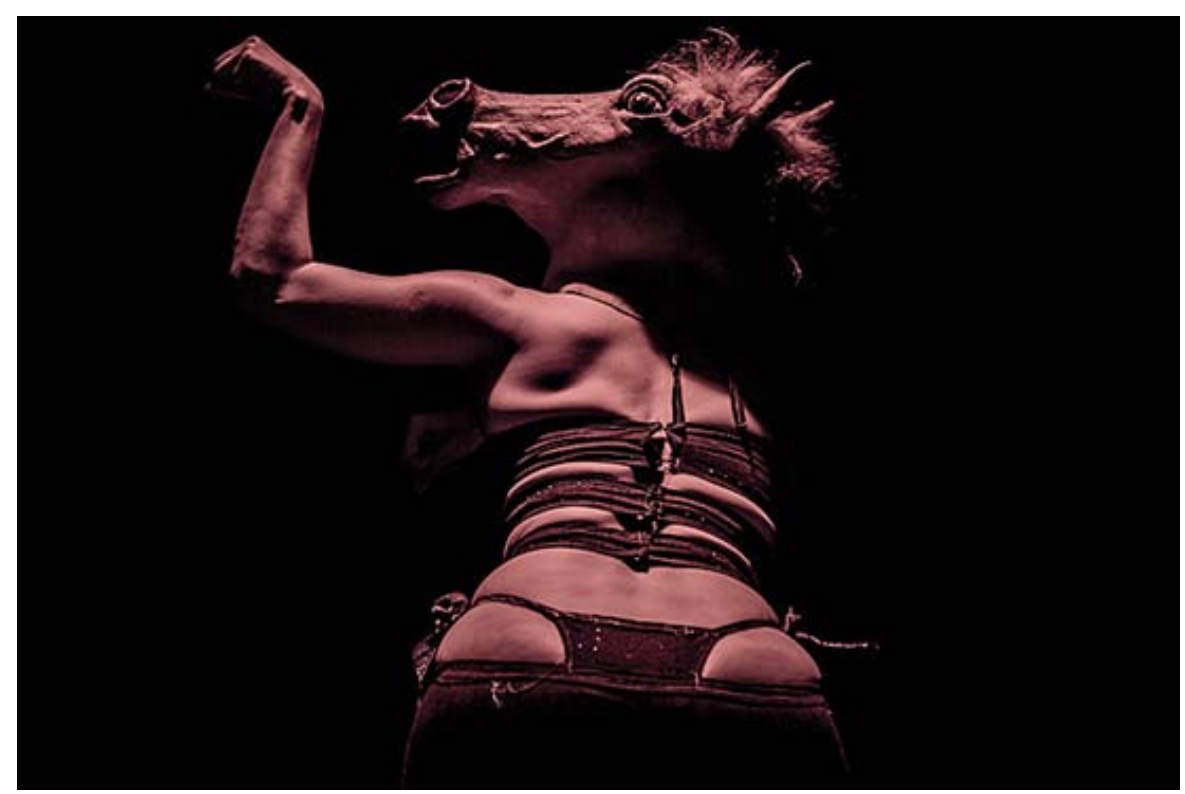

Imagem 3: Cena de Galega dançando em uma boate noturna com roupa sensual e cabeça de égua em Boi Neon (Gabriel Mascaro, 2015) | C Folha de São Paulo (2016)

A mulher vestida com cabeça de égua (animal) leva a proposta narrativa de Mascaro ao seu auge, pois na figuração da última cena inúmeros signos estão relacionados por contradições, mas unidos por sua dimensão político-econômica de trabalhadoramercadoria que recebe em troca seu valor pecuniário, assim como são inseridos os animais na arena do rodeio. A relação política mulher/plateia é economia mediada por regras culturais ou tácitas, legislativas e governamentais, que determinam politicamente os comportamentos recíprocos no campo da sexualidade desviada de suas funções ou finalidades primárias, de modo que nenhuma atitude pode colocar em risco certa coesão social ou comunitária, mesmo que tal sociabilidade seja constituída e permeada por contradições e conflitos no campo dos debates sobre gênero e sexualidade.

A sexualidade feminina mais uma vez é trazida ao filme pela dimensão tecnológica numa cena em que Galega está na cabine de seu caminhão no estacionamento de um centro de vendas têxtil. Ela está com sua filha Cacá esperando Iremar, que foi comprar algo no interior do comércio. Um vendedor ambulante a surpreende, vendendo calcinha "fio dental". Os dois estabelecem um "diálogo 
erótico" e Galega compra três calcinhas. Quando o vendedor sai de cena, Cacá julga e qualifica sua mãe com a seguinte frase: "Calcinha de puta”. De imediato sua mãe (Galega) lhe bofeteia o rosto.

No devir histórico da sexualidade a divisão sexual entre homens e mulheres foi marcada pelo confinamento, ou pela negação da resposta sexual feminina, em detrimento da permissividade masculina em relação ao sexo. O homem pode ter sexo com várias mulheres e de forma promíscua, e isso moralmente não o afeta de forma negativa. Esse comportamento, sob a óptica do feminino, tem conotações políticas opostas e serve de medida para se classificar uma mulher como pura (naturalmente destinada à beleza e à procriação) ou impura (econômica e culturalmente desviada de suas funções ou finalidades supostamente naturais). Em grande parte, isso tem relação com os modos de como a maternidade foi construída e se tornou um componente básico de domínio feminino. "Porém, quanto mais a sexualidade desassociou-se da reprodução e integrouse em um emergente projeto reflexivo do eu, mais esse sistema institucional de repressão ficou sob tensão" (Giddens 1993, 196). “A reinvindicação do prazer sexual feminino veio a se transformar em [...] reconstituição da intimidade, uma emancipação tão importante quanto qualquer outra buscada na esfera pública" (Giddens 1993, 196).

Em todas as sociedades e em diferentes momentos históricos existiram sexualidades consideradas boas, normais, saudáveis e outras consideradas como más, imorais e perigosas para a saúde. $\mathrm{O}$ projeto de modernidade configura - no bojo de um debate das interações entre natureza e cultura, passando pelo romantismo e pela eugenia - a relação heterosexual como a ideal. Não perdendo de vista a face metafísica da vida, essa relação deveria ou deve ainda acontecer no marco do reconhecimento religioso ou laico do matrimônio). Se possível, entre pessoas de uma mesma geração (faixas etárias próximas) e raça, preferencialmente sem intermediação financeira, a fim de evidenciar a mediação amorosa enquanto base da família humana (procriação) no lugar do cio instintivo; sem o intermédio da violência e a despeito de objetos que sexualizem os corpos. Deveria ser feita entre duas pessoas - nem sozinho, nem entre três ou mais pessoas (triângulos ou quadrilhas amorosos).

\section{O público e o privado, o externo e o íntimo}

Regras como as brevemente acima citadas demonstram o quanto a sexualidade, necessariamente implicada no campo da alteridade física ou imaginária, é um fenômeno político, porque não possui a mediação dos instintos ou da suposta teleologia reprodutiva da natureza, nos remetendo a pensar a vinculação íntima dos usos do corpo nos domínios dos poderes públicos e privados em um campo 
de conflitos entre razão e desejo (Turner 1989). Como afirma Paul B. Preciado, "os contextos sexuais se estabelecem por meio de delimitações espaço-temporais oblíquas. A arquitetura é política. É ela que organiza as práticas e as qualifica: públicas ou privadas, institucionais ou domésticas, sociais ou íntimas" (2014, 31). Dessa forma, passamos agora a analisar algumas cenas de Boi Neon que tensionam questões políticas ligadas à intimidade.

O filme dirigido por Mascaro realiza um jogo de imagens em que são alternadas práticas públicas e privadas/íntimas concernentes aos usos dos corpos. Entre essas modalidades práticas da vida, a questão do comum é transversal, mas se distingue entre o comumrevelado (público) e o comum-velado (privado). Algumas práticas corporais consideradas de foro íntimo, como no caso de alguns procedimentos de higiene, são comuns aos seres humanos no interior de uma cultura baseada em conhecimentos de saúde-doença, mas raramente são incluídas nas narrativas artísticas. Assim, muitas práticas são excluídas do campo das espectorialidades, mas são extremamente comuns na intimidade. De um certo ponto de vista, a intimidade banal e cotidiana no invólucro da vida privada aparece como estranha e incômoda quando extrapolada para a visualidade pública, onde deve ser reprimida.

As práticas sexuais, certamente, ao lado das necessidades fisiológicas, bem como os procedimentos de higiene, fazem parte desse escopo por excelência, pois, embora sejam comuns aos seres sexuados, no caso dos humanos estão regidas por regras que levam em consideração os limites do público-privado, limites estes há muito explorados pelos conteúdos e pelas formas cinematográficas. O cinema, portanto, é metaforicamente a janela que se abre para o privado desde uma perspectiva pública semelhante ao voyeurismo. Sem embargo, as imagens da intimidade ferem ou rasgam a paisagem da cena pública, de modo a causar as mais diversas emoções e comoções.

Refletindo sobre as práticas sexuais mediadas por variáveis econômicas (a exemplo dos espaços chamados de bordéis e da prostituição), essas são frequentemente utilizadas pelo cinema porque são as facetas ou liames primários dos comportamentos privados e, muitas vezes secretos, dos corpos que irrompem o espaço público, geralmente mediante organizações coletivas, traço comum aos espetáculos de strip tease ou de danças sensuais, que em Boi Neon são representadas por Galega.

Nessa direção, em que a película alterna e inverte as relações do público e do privado no espaço das visualidades, podemos iniciar discutindo sobre duas cenas de sexo expostas no filme. Júnior (o rapaz que alisa seus longos cabelos com chapinha) e Galega (a mulher que dirige caminhão) fazem sexo a céu aberto, numa noite, na cocheira onde comem e bebem os bois. Eles transam ali mesmo 
entre os animais. Os limites da intimidade não estão demarcados por quatro paredes; de igual forma os animais estão ali inertes ou indiferentes, a poucos metros, diante da relação natural e culturalmente banal dos corpos humanos que transam para esteticamente provocar o público deste lado da tela. Considerando a cocheira como espaço público voltado a outras finalidades, ela abriga na cena uma prática comum aos espaços privados da humanidade, mas num lugar comum aos animais. Única e exclusivamente, pelo fato de a cocheira estar colocada como espaço fílmico lançado à espectorialidade, o íntimo comum velado é revelado na cena em que o público possa se reconhecer na dimensão comunitária do sexo, mesmo que isso tenha que ocorrer por uma fissura do véu da moralidade pública; fazendo do cinema uma experiência limite.

Existe uma infinidade de leis estatais e ditames culturais, mais ou menos tácitos, que conformam a norma dos comportamentos políticos ou relacionais no que tange à sexualidade sob os ditames da intimidade. $\mathrm{O}$ sexo esteve sempre ligado ao âmbito do íntimo; historicamente se desenvolve narrado como pertencente à esfera do privado, tocando as fronteiras com o público. Esta "regra" da intimidade está constantemente sendo tensionada por transgressões, na medida em que, na atualidade, o voyerismo e o exibicionismo clássicos, em todas suas variantes, foram potencializados e banalizados pelos dispositivos das tecnologias digitais ligadas à imagem. Sites e aplicativos de busca de parceiro sexuais; selfies eróticas; vídeos caseiros de sexo amador postados por pessoas comuns (não profissionais) via Internet em sites de pornografia, entre outras, todas são manifestações que estreitam os tênues límites entre o público e o privado da sexualidade reconhecida e localizada no lugar comum da intimidade velada.

Ainda sobre essa cena, no início da relação sexual, Junior está de joelhos fazendo sexo oral em Galega, que está em pé. Quando ele para e começa a se levantar, Galega faz um movimento de resistência em sua cabeça para que ele não se levante e diz: "Não pare". No eixo da desnaturalização das finalidades da sexualidade e da animalidade, o sexo oral, assim como o anal, historicamente foram vistos como perversões que não fazem parte de uma natureza reprodutiva. A anatomia corporal implica uma organização moral e higiênica das relações entre suas regiões permitidas e proibidas para o sexo (Preciado, 2014). O ânus, a boca e a mão foram fortemente controlados pela regulação sexopolítica anti-masturbartória e antihomossexual. Mediante seu gesto discreto, Galega recoloca a oralidade de Junior no eixo dos desvios, bem como ela o desvia de certa teleologia masculina voltada para o domínio da fêmea.

O par prazer/sexo, como um mediador causal das relações humanas, é regido por princípios políticos que medem as consequências dos encontros. Pensando os sexos oral e anal como alternativas inférteis do prazer, em sociedades voltadas para o 
princípio da família por procriação (e não por amizade ou adoção), os signos boca-vagina, boca-pênis, boca-ânus, pênis-ânus edificam relações cuja lógica não tem como desdobramento a cria, bem como, independente de ser anticoncepcional, é uma modalidade de prazer.

Outra cena é mais intrigante e tem uma duração aproximada de seis minutos. Iremar (o estilista de moda) vai, à noite, à empresa onde trabalha Geise (vendedora de cosméticos e vigilante noturna) para agradecer o perfume que ela deixou para ele no caminhão durante a manhã, enquanto ele não estava. Ela o convida para entrar e mostra a empresa têxtil, que o deixa boquiaberto. Os dois transam sobre uma mesa de talhar tecidos dentro do imenso galpão da fábrica. Assim como Junior e Galega, comentados acima, Iremar e Geise pervertem as finalidades tanto do ambiente quanto do corpo. Mesa de talhar e corpo de grávida não são lugares nem regiões consensualmente autorizados para o sexo e o prazer. Debaixo da farda e do coturno, está um corpo feminino prestes a sangrar o parto de um filho. A relação sexual ocorre sobre a mesa de talhar destinada à penetração repetitiva de lâminas cortantes através dos tecidos.

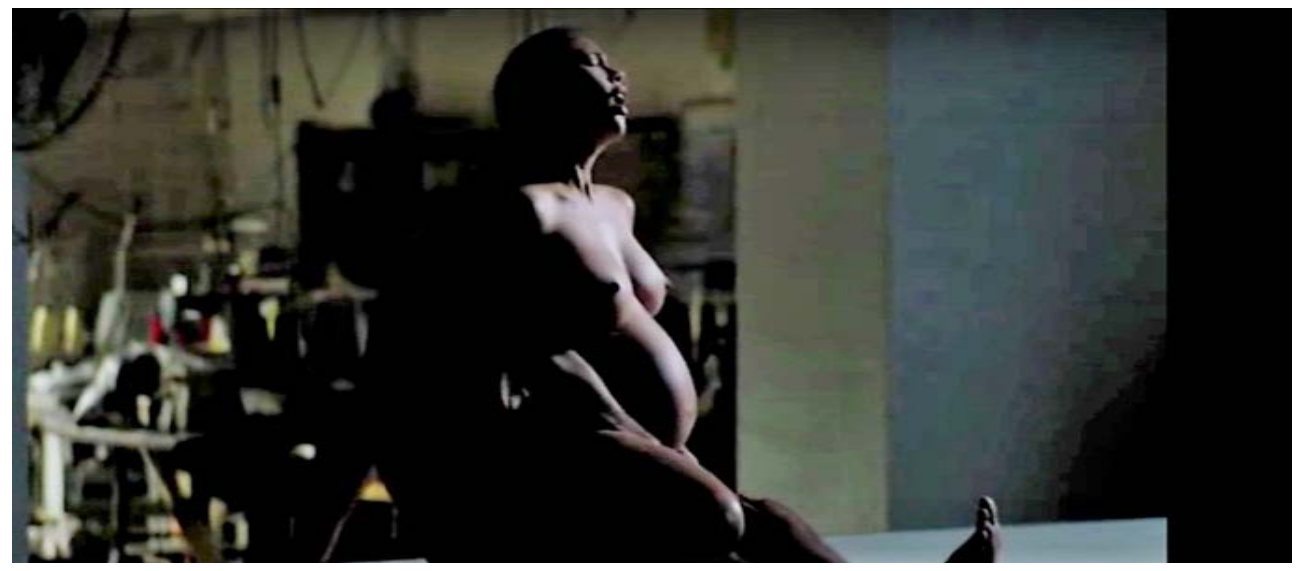

Imagem 4: Cena de Iremar e Geise tendo relações sexuais sobre a mesa de talhar tecido numa fábrica textil em Boi Neon (Gabriel Mascaro, 2015) | (C) Gabriel Mascaro

O distanciamento da sexualidade como prática de reprodução e a reivindicação do prazer sexual feminino fez com que o que se costumava ser chamado de perversões se transformasse apenas em expressões de como a sexualidade pode ser legitimadamente revelada e a auto identidade definida (Giddens 1993).

Um banheiro coletivo com vários homens nus tomando banho é outra cena que deixa o espectador em estado de estranhamento no âmbito das questões políticas da intimidade. São quase dois minutos de cena em que homens se banham com baldes e bacias, num banheiro com um único chuveiro. Um misto de nove corpos nus que mostram músculo, gordura, marcas de diversas idades. A nudez é o 
lugar onde o corpo se revela para o olhar, como esboça José Luís Barrios:

el desnudo en el arte pone en juego las relaciones entre mirada, deseo y poder. La geografía, la geología y la geopolítica del cuerpo desnudo nos hablan de los dispositivos con los que la cultura construye la representación de si y del otro. (Barrios 2007, 134)

As cenas longas e sem fala são características nos filmes de Mascaro. Em Boi Neon, se evidenciam as marcas do silêncio como experiência sensível colocada em primeiro plano em cenas longas para que a imagem seja a palavra. Por essa via, a estética do tempo em Mascaro implica a problemática da duração do olhar para o cinema, em face de sua história atrelada à pintura. Na verdade, o tempo de exposição da imagem para o olhar é uma questão pictórica que determinou desenvolvimentos técnicos e tecnológicos desde os pintores aos cineastas, passando pelos fotógrafos e suas máquinas de capturar imagens. O tempo de exibição de um corpo velado ou revelado pode evidenciar os limites entre o estranho e o familiar; entre o conforto e o desconforto imersos na experiência da alteridade.

Agora destacamos a cena em que Galega se depila no caminhão, que antecede e prepara as cenas acima descritas do sexo na cocheira. A personagem fecha as cortinas da cabine, separando privado e público na relação campo e extra-campo da filmagem. Contudo, como um paradoxo próprio das artes visuais, o campo da intimidade corporal é revelado ao espectador pelo par câmera/ecrã que, excluído do espaço-tempo da cena, no espaço público extracampo da espectorialidade ${ }^{12}$, fenomenologicamente parece ter seus olhos colocados no interior da cabine do caminhão, a câmara escura da intimidade. Galega abre as pernas (para o público expectante) e coloca os pés sobre o painel e com cera quente se depila. $\mathrm{O}$ ato antinatural de impedir a expressão filogenética de suas pelugens de fêmea revela na expressão facial e sonora um sentimento de dor que se projeta para o prazer noturno programado pelo encontro com Junior.

Exibida para o público espectante, Galega barra Cacá (sua filha) que vem lhe pedir algo, ao solicitar que retorne depois. Não quer ser incomodada, pois tem um encontro sexual com Júnior. $\mathrm{O}$ olhar do público extra-campo é privilegiado em face de uma intimidade negada à filha, possivelmente porque o espectador tem o poder de observar o secreto, mas não de intervir sobre ele. Em

\footnotetext{
12 Nossa concepção de extra-campo está fundamentada em suas duas possibilidades de sentido segundo Deleuze. Na primeira, mais comum, extracampo se limita ao espaço e ao tempo visuais e sonoros imediatos, contíguos e sincrônico (homogêneo) à filmagem de um plano ou enquadramento. Na segunda, extra-campo implica o universo como um todo passível de participar da experiência cinematográfica, considerando, portanto, o espectador (Augusto 2004, 42-45; Weschefelder 2016).
} 
relação à personagem Cacá lhe é impossibilitado o acesso visual ao interior da cabine, mas o som de sua voz atravessa vidros e cortinas para incomodar fazendo vibrar as membranas auditivas de Galega, cuja voz desde a intimidade se projeta para fora do caminhão e da câmera/tela.

Sobre a maternidade, experiência radical da alteridade humana, em que a mãe abandona seu corpo ao desviar, durante um dado período de vida, seu olhar, seu toque, suas forças no sentido dos filhos, cuja cultura clássica fixou a identidade da mulher, realiza o papel de desligar a prole de sua intimidade sexual (então direcionada para a procriação) demarcadas pela visualidade da vagina (parto) e dos seios (amamentação); então entregues à "passividade" do espectador e para a atividade da contracena sexual. De uma dada perspectiva, essa cena de Galega com sua filha sintetiza a complexidade relacional ou política público-privada, demarcada pelo território do cinema em que a espectorialidade se defronta com a estética da intimidade e suas perversões sexualizadas, evidenciando a dimensão política do corpo em oposição às mediações instituais do animal, que modernamente também foi desviado da natureza a fim de atender dinâmicas da economia e da cultura contemporâneas.

\section{Considerações finais}

Retomando o objetivo do texto, que foi tensionar questões políticas que giram em torno do corpo a partir das questões do gênero, da sexualidade e da intimidade a partir do filme Boi Neon, percebe-se na narrativa fílmica de Gabriel Mascaro significações que ironizam dispositivos sexopolíticos que emergiram do capitalismo disciplinário a partir da modernidade. Em vários momentos, as verdades, visualidades e formas de exteriorização do gênero, da sexualidade e da intimidade em Boi Neon são desconstruídos e resignificados no que tange às suas formas históricas de produção e controle.

O corpo moderno é um corpo produzido e sua produção tem relações íntimas com a economia capitalista neoliberal. A sexualidade e a heteronormatividade de gênero são consequências de um modelo médico e farmacológico que lhes dão suportes teóricos e que estão em consonância com técnicas do corpo institucionalizadas e juridicamente materializadas. $\mathrm{O}$ filme dirigido por Mascaro oculta alguns desses dispositivos em sua narrativa, na medida em que expõe, de forma invertida, tradicionais dicotomias: masculino/feminino; homem/animal; público/privado. Em síntese, num contexto rural, onde o pó atravessa o visual, onde os bois formam parte da paisagem, onde os instintos estão à flor de pele, ali a política acha as fissuras, os interstícios por onde configurar as 
práticas, que, por mais íntimas ou particulares que possam parecer, são sempre sociais.

\section{BIBLIOGRAFIA}

Augusto, Maria de Fátima. 2004. A montagem cinematográfica e a lógica das imagens. São Paulo: Annablume; Belo Horizonte, FUMEC.

Barrios, José Luis. 2006. "Lo colosal y lo terrorífico: el cuerpo en el régimen de la contemporaneidad." In Cuerpo y subjetividade, Gabriel Cachorro (comp.), 103-138. La Plata: Editorial Universidad Nacional de La Plata.

Butler, Judith. 2014. "Regulações de gênero." Cadernos Pagu 42 (janjun): 250-274.

Costa, Tammy Rocha e Fabio Zoboli. 2014. "O discurso da sexualidade na revista Playboy onde figuram mulheres atletas." Monografia apresentada ao Departamento de Educação Física da Universidade Federal de Sergipe.

Deleuze, Gilles. 2009. Cine I: Bergson y las imágenes. Buenos Aires: Cactus.

Figueirôa, Alexandre. 2000. Cinema pernambucano: uma história em ciclos. Recife: Fundação de Cultura Cidade do Recife.

-_- 2010. "O ciclo do Recife e a entrada do Nordeste na modernidade audiovisual”. In Nordeste, memórias e narrativas da mídia, Geísa Mattos et al. (orgs.), 206-221. Fortaleza: Edições Iris/ Expressão Gráfica Editora.

Folha de São Paulo. 2016. “Artistas aposentam imagem do cabra macho e reafirmam sertão sofisticado". Publicado em 10/02/2016. Disponível em: http://www1.folha.uol.com.br/ilustrada/2016/02/1738214artistas-aposentam-imagem-do-cabra-macho-e-reafirmamsertao-sofisticado.shtml. Acesso em 20/05/2018.

Foucault, Michel. 2009 [1976]. História da sexualidade I: A vontade de saber. 19a ed. Tradução de Maria Tereza da Costa Albuquerque e J. A. Guilhon Albuquerque. Rio de Janeiro: Edições Graal.

—_- 2001. Vigiar e Punir: história da violência nas prisões. $22^{\mathrm{a}}$ ed. Petrópolis, RJ: Vozes.

Galak, Eduardo. 2017. "Educar (con) la mirada. Discursos políticos y sentidos estéticos sobre la cultura física en noticieros cinematográficos.” In Gregorio Weinberg: escritos en su honor, 
Gabriela Ossenbach Sauter (ed.), 55-74. Buenos Aires: CLACSO.

Galimberti, Umberto. 2006. Psiche e techne: o homem na idade da técnica. Tradução de José Maria de Almeida. São Paulo: Paulus.

Giddens, Anthony. 1993. A transformação da intimidade: sexualidade, amor \& erotismo nas sociedades modernas. Tradução de Magda Lopes. São Paulo: Editora da Universidade Estadual Paulista.

Mauss, Marcel. 1974. “As Técnicas Corporais”. In Sociologia e Antropologia, Marcel Mauss, 385-407. São Paulo: EPU/EDUSP.

Milner, Jean-Claude. 2013. Por una política de los seres hablantes: breve tratado político II. $1^{\mathrm{a}}$ ed. Olivos: Grama Ediciones.

Preciado, Paul Beatriz. 2014. Manifesto contrassexual. Tradução de Maria Paula Gurgel Ribeiro. São Paulo: n-1 edições.

Rancière, Jacques. 2011a. El malestar en la estética. Tradução de Miguel Angel Petrecca, Lúcia Vogelfang e Marcelo G. Burello. Buenos Aires: Capital intelectual.

_-_. 2011b. El destino de las imágenes. Buenos Aires: Prometeo libros.

-——. 2009. A partilha do sensível: estética e política. Tradução de Mônica Costa Neto. São Paulo: Editora 34.

Turner, Bryan S. 1989. El cuerpo y la sociedad: exploraciones en teoría social. Tradução de Eric Herrán Salvatti. México: FCE.

Weschefelder, Ricardo. 2016. "O conceito de extra-campo no cinema: o plano invisível”. Linguagens Revista de Letras, Artes e Comunicação, v. 10, n. 2 (mai./ago): p. 306-320.

\section{FILMOGRAFIA}

Boi Neon [longa-metragem]. Dir. Gabriel Mascaro. Desvia Produções, Brasil, 2015. 101 mins. 